\title{
SPECIFICATION FOR 20,000 GALLON LIQUID NITROGEN STORAGE TANK
}

\author{
D-ZERO PROJECT \\ FERMILAB \\ G.T. MULHOLLAND \\ G. STEPANEK \\ C.H. KURIT A
}

D-Zero Engineering Note: $3740.513-E N-79$

JANUARY 1987

REV A

JULY 1987

REV B

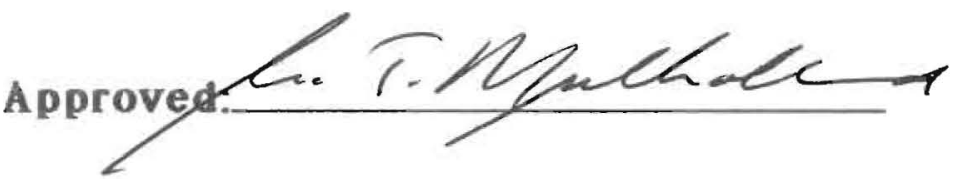


LIQUID NITROGEN STORAGE TANK SPECIFICATION PAGE 2

\section{$1.0 \quad$ SCOPE}

I.1 THIS SPECIFICATION DEFINES THE REQUIREMENTS FOR A LIQUID NITROGEN STORAGE TANK TO BE INSTALLED AT FERMILAB, BATAVIA, ILLINOIS.

\subsection{IANK DATA}

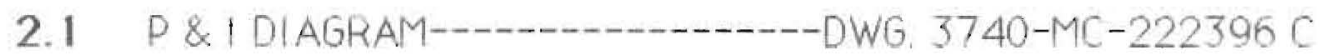

2.2 CONFIGURATION----- 10 FT DIA, HORIZONTAL

2.3 CAPACITY

2.3.1 WATER VOLUME------20,000 GALLONS

2.3.2 LIQUID NITROGEN VOLUME AT TRYCOCK-19,000 GALLONS

2.4 MAXIMUM ALLOWABLE WORKING PRESSURE--65 PSIG, VACUUM

2.5 MINIMUM ALLOWABLE TEMPERATURE------ -320 DEG F

2.6 REQUIRED DISCHARGE CAPACITY

2.6.1 40 GPMMAX

2.6.2- 20 GPM NOM

2.7 REQUIRED TANK OPERATING PRESSURE-....- 30 PSIG

2.8 OPERATION-

2.9 FILLING

2.9.1 - FROM COMMERCIAL HIGHWAY TRANSPORT

2.10 NORMAL EVAPORATION RATE ---- NOT TO EXCEED $0.30 \%$ OF CAPACITY PER DAY AT 50 MILLITORR VACUUM

2.11 MOUNTING ---- TWO SADDLES OR FOUR LEGS, WITH PROVISION FOR ANCHOR BOLTS, FOR INSTALLATION ON BUYER'S CONCRETE PIERS 
LIQUID NITROGEN STORAGE TANK SPECIFICATION PAGE 4

3.4.3 GAGE CONNECTIONS AND SAFETY DEVICE CONNECTIONS SHALL BE THREADED AND MADE UP WITH OXYGENCOMPATIBLE THREAD SEALANT. OTHER JOINTS SHALL BE SILVER BRAZED FOR COPPER OR COPPER ALLOYS, OR WELDED FOR STAINLESS STEEL.

3.4.4 PIPING CONNECTED TO THE INNER VESSEL SHALL INCLUDE

3.4.4.1 TOP TRANSPORT FILL LINE, CONNECTING TO VAPOR PHASE, AND HAVING A SPLASH PLATE OR SPRAY INSIDE INNER VESSEL.

3.4.4.2 VENT AND SAFETY RELIEF LINE, CONNECTING TO VAPOR PHASE.

3.4.4.3 BOTTOM FILL LINE,CONNECTING TO THE LIQUID PHASE AND HAVING A DEFLECTOR INSIDE THE INNER VESSEL.

3.4.4.4 PRESSURE BUILD LIQUID FEED LINE AS CLOSE AS POSSIBLE TO THE BOTTOM.

3.4.4.5 PRESSURE BUILD VAPOR RETURN LINE, CONNECTING TO VAPOR PHASE.

3.4.4.6 LIQUID DELIVERY LINES CONNECTING TO THE LIQUID PHASE AND THREE INCHES FROM THE BOTTOM.

3.4.4.7 FULL TRYCOCK LINE, HAVING ITS OPENING AT THE 19,000 GALLON LEVEL.

3.4.4.8 TOP LIQUID LEVEL GAGE LINE, CONNECTING TO THE VAPOR PHASE.

3.4.4.9 BOTTOM LIQUID LEVEL GAGE LINE, CONNECTING TO LIQUID PHASE AS CLOSE AS POSSIBLE TO THE BOTTOM. 


\section{LIQUID NITROGEN STORAGE TANK SPECIFICATION PAGE 5}

3.4.4.10 PRESSURE REGULATING VENT VALVE SHALL BE SUPPLIED AS INDICATED ON SCHEMATIC.

3.4.4.11 MANUAL BLOWDOWN VALVE, 1 1/2".

3.4.5 VALVES

3.4.5.1 ALL VALVES SHALL BE SUITABLE FOR THEIR APPLICATION.

3.4.5.2 ALL COLD VALVES SHALL HAVE EXTENDED STEMS AND BONNETS.

3.4.5.3 PNEUMATIC ACTUATORS AND POSITIONERS (FISCHER) SHALL BE SUPPLIED AS INDICATED ON THE SCHEMATIC.

\subsection{FILL SYSTEM}

3.5.1 A CGA STANDARD $11 / 2^{\prime \prime}$ NITROGEN HOSE CONNECTOR SHALL BE PROVIDED.

3.5.2 A FILL CHECK VALVE SHALL BE PROVIDED, INBOARD OF THE HOSE CONNECTOR.

3.5.3 A HOSE SAFETY VALVE AND A HOSE BLOWDOWN VALVE SHALL BE PROVIDED, INBOARD OF THE FILL CHECK VALVE.

3.5.4 INBOARD OF THE HOSE SAFETY AND HOSE BLOWDOWN, THE FILL LINE SHALL TEE OFF TO A TOP FILL VALVE (LEADING TO THE LINE IN 3.4.4.1) AND A BOTTOM FILL VALVE (LEADING TO THE LINE IN 3.4.4.3).

3.6 LIQUID DELIVERY LINE

3.6.1 THE LINES OF 3.4.4.6 SHALL BE EQUIPPED WITH A FULL LINE SIZE VACUUM-JACKETED VALVE AND BAYONET ASSEMBLIES,

3.6.1.1 THE BAYONET AND VALVE ASSEMBLIES SHALL BE CRYOLAB $11 / 2 "$ " DWG. CV-1299, TOMATE WITH PURCHASERS $V-J$ DSTRIBUTION PIPING. 


\section{LIQUID NITROGEN STORAGE TANK SPECIFICATION PAGE 6}

3.6.2 THE VACUUM SYSTEM OF THE VALVE AND BAYONET ASSEMBLY SHALL BE SEPARATE FROM THE TANK VACUUM SYSTEM.

3.6.3 1/2" AUXILIARY LIQUID WITHDRAWL LINE.

\subsection{SAFETY DEVICES}

3.7.1 THE INNER VESSEL. SHALL BE PROTECTED FROM EXCESSIVE INTERNAL PRESSURE BY A SYSTEM OF TWO SAFETY RELIEF VALVES, TWO RUPTURE DISCS, AND AN EXTENDED STEM SELECTOR VALVE WITH ONE SAFETY RELIEF VALVE, AND ONE RUPTURE DISC ON EACH OUTLET OF THE SELECTOR VALVE.

3.7.1.1 THE SELECTOR VALVE SHALL BE SUCH THAT AT LEAST ONE OUTLET IS ALWAYS OPEN TO THE INNER VESSEL.

3.7.1.2 THE CAPACITIES OF EACH SAFETY RELIEF VALVE AND EACH RUPTURE DISC SHALL BE AS REQUIRED BY COMPRESSED GAS ASSOCIATION PAMPHLET S-1.3, OR 2" WHICHEVER IS LARGER.

3.7.2 THE OUTER VESSEL SHALL BE PROTECTED BY RELIEF DEVICES HAVING A DISCHARGE AREA OF AT LEAST 50 SQUARE INCHES AND OPENING AT A PRESSURE NOT MORE THAN THE LESSER OF THE INTERNAL DESIGN OF THE OUTER VESSEL (AS CALCULATED BY THE ASME CODE) OR 15 PSIG.

3.7.3 ALL PIPING SECTIONS IN WHICH LIQUID NITROGEN OR VERY COLD GASEOUS NITROGEN COULD BE TRAPPED BY MANUAL OR AUTOMATIC CLOSING OF VALVES SHALL BE PROTECTED BY SUITABLE SAFETY RELIEF VALVES. 
LIQUID NITROGEN STORAGE TANK SPECIFICATION PAGE 7

3.8 GAGES

3.8.1 THE TANK SHALL BE PROVIDED WITH A DIFFERENTIAL PRESSURE LIQUID LEVEL GAGE, CONNECTED BETWEEN THE TOP AND BOTTOM GAGE LINES (3.4.4.8 AND 3.4.4.9 ABOVE). TWO SHUT-OFF VALVES AND A BY-PASS VALVE SHALL BE PROVIDED.

3.8.2 THE TANK SHALL BE PROVIDED WITH A PRESSURE GAGE, CONNECTED TO THE TOP GAGE LINE (3.4.4.8 ABOVE).

3.8.3 THE TANK SHALL BE PROVIDED WITH A HASTINGS THERMOCOUPLE VACUUM GAGE SENSING TUBE, CONNECTED TO THE VACUUM SPACE THROUGH A SUITABLE VALVE AND PERLITE FILTER.

3.8.4 A BATTERY-POWERED PORTABLE THERMOCOUPLE VACUUM GAGE READ-OUT SHALL BE PROVIDED FOR THE TANK.

3.9 PRESSURE BUILDING SYSTEM

3.9.1 THE TANK SHALL BE PROVIDED WITH A PRESSURE BUILD-UP SYSTEM, COMPLETE WITH AMBIENT AIR HEATED VAPORIZING HEAT EXCHANGER.

3.9.2 THIS SYSTEM SHALL INCLUDE A LIQUID SUPPLY LINE WITH SHUT-OFF VALVE (MAY BE BRANCHED OFF BOTTOM FILL LINE); A VAPOR RETURN LINE (3.4.4.5) WITH A SHUT-OFF VALVE; A PNEUMATIC PRESSURE VALVE; NECESSARY PIPING SAFETY VALVES (3.7.3); IF HEAT EXCHANGER IS SHIPPED LOOSE, FLANGES FOR FIELD CONNECTIONS TO AND FROM HEAT EXCHANGER.

3.9.3 THIS SYSTEM SHALL BE SIZED TO MAINTAIN TANK PRESSURE PER 2.8 WHILE LIQUID NITROGEN IS DELIVERED PER 2.6 SO LONG AS THE LIQUID NITROGEN DEPTH IS TWO FEET OR MORE.

3.9.4 THE LOCATION OF THE PRESSURE BUILDING SYSTEM RELATIVE TO THE STORAGE TANK WILL BE AGREED UPON AT THE TIME OF CONTRACT AWARD. 


\subsection{TESTING AND DOCUMENTATION}

IN ADDITION TO TESTING REQUIRED BY THE ASME CODE

4.1 THE TANK SHALL BE HELIUM MASS-SPECTROMETER (1 E-8 STD CC/SEC) TESTED FOR VACUUM-TIGHTNESS OF INNER AND OUTER VESSELS.

4.2 PIPING SHALL BE TESTED AT 80\% OF M.A.W.P. AND ALL JOINTS, INCLUDING SAFETY DEVICE INLET CONNECTIONS, SHALL BE SOAP AND BUBBLE CHECKED FOR LEAKAGE.

4.3 THE MANUFACTURER SHALL FURNISH TO THE BUYER THE CODE UI-A FORM AND CERTIFICATE(S) OF MASS-SPECTROMETER AND PIPING TESTS.

\subsection{WARRANTY}

5.1 VACUUM: VACUUM NOT TO EXCEED 200 MICRONS COLO 12 MONTHS AFTER START-UP OR 18 MONTHS AFTER SHIPMENT, WHICHEVER COMES FIRST

5.2 GENERAL: MANUFACTURER TO WARRANT MATERIAL AND WORKMANSHIP FOR A PERIOD OF ONE YEAR FROM START-UP OR18 MONTHS FROM SHIPMENT, WHICHEVER COMES FIRST. 


\begin{tabular}{|c|c|c|c|}
\hline |REV. & DESCRIPTION & Domes & ant \\
\hline & GENERAL REVISIONS & S.L.M. & $\overline{6-12-86}$ \\
\hline A & & & \\
\hline$B$ & GENERAL REVISIONS & S.L.M. & $9-9-86$ \\
\hline C & ADDED MV505IN AND NOTES & S.L.M. & $2-24-87$ \\
\hline$D$ & ADDED PSV5052N & $\begin{array}{l}\text { S.L.M. } \\
\text { K.KREMPET }\end{array}$ & $\frac{8-27-87}{8-27-87}$ \\
\hline
\end{tabular}

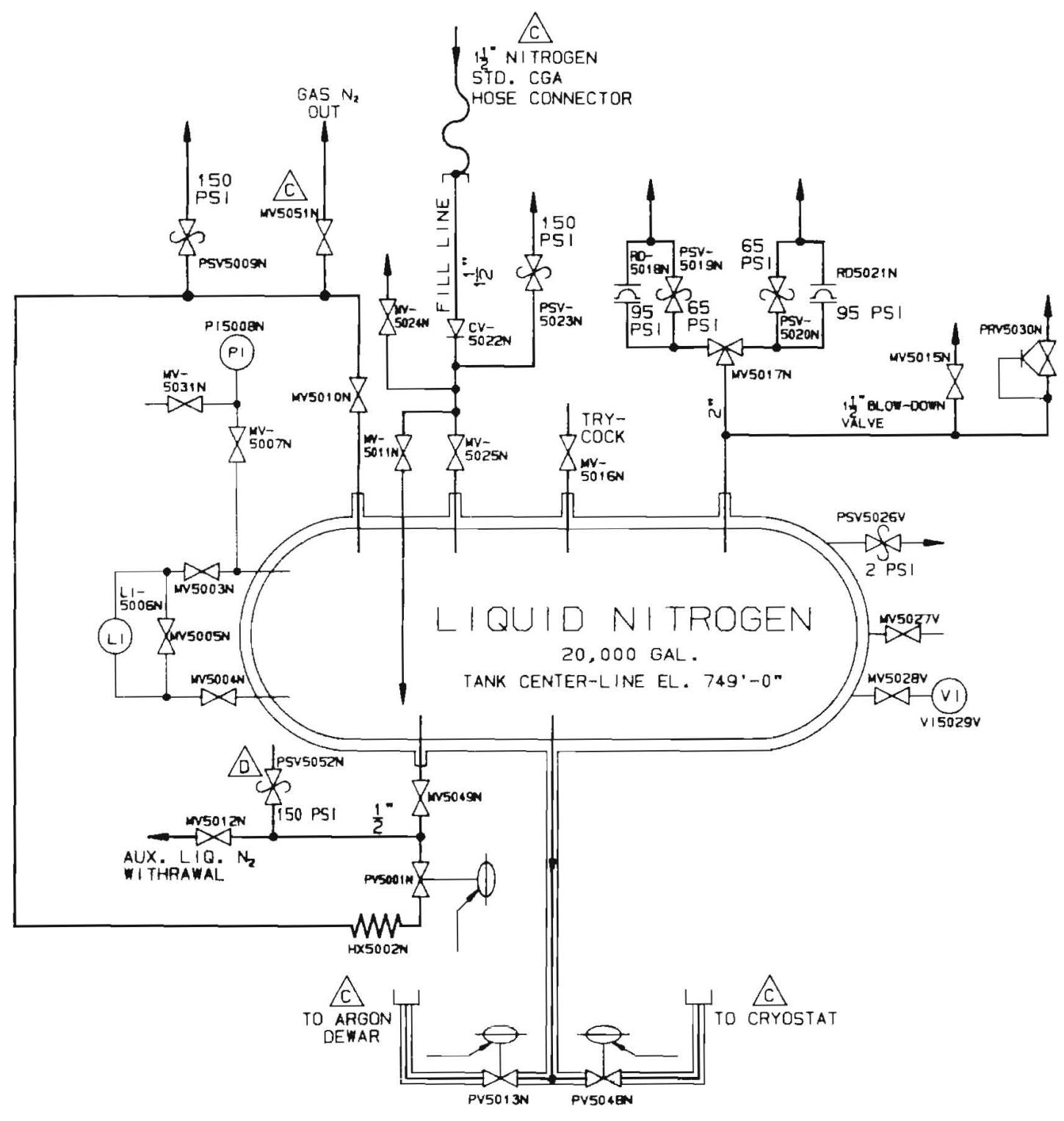

LIQUID NITROGEN LINES

VACUUM, INSTRUMENTATION, AND OTHER LINES

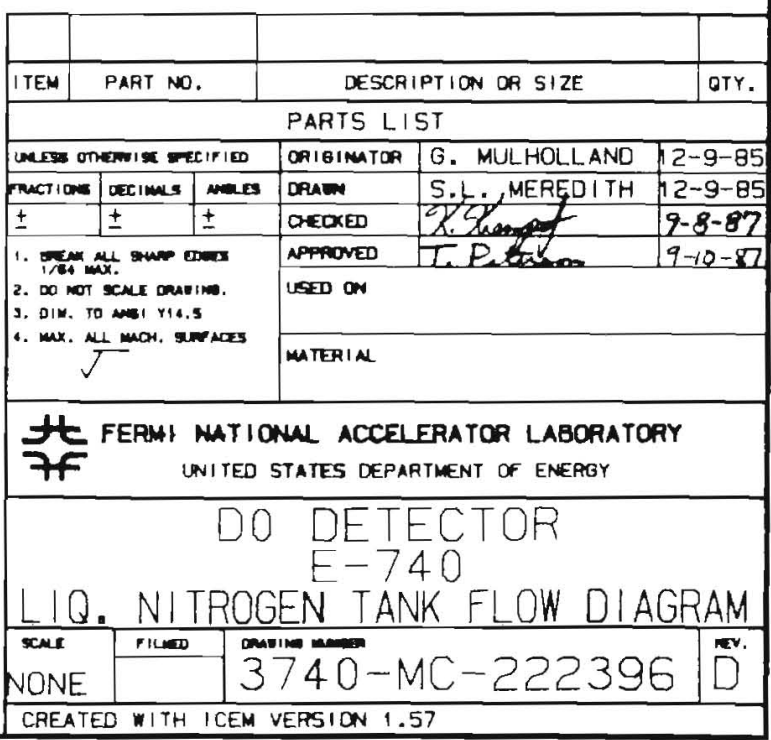

